\title{
sciendo
}

\section{ANALYSIS OF LIFETIME PERFORMANCE AND CULLING REASONS IN BLACK-AND-WHITE HOLSTEIN-FRIESIAN COWS COMPARED WITH CROSSBREDS*}

\author{
Krzysztof Adamczyk $^{1 \star}$, Wojciech Jagusiak², Joanna Makulska ${ }^{1}$ \\ ${ }^{1}$ Department of Cattle Breeding, Institute of Animal Sciences, \\ ${ }^{2}$ Department of Genetics and Animal Breeding, \\ University of Agriculture in Krakow, Al. Mickiewicza 24/28, 30-059 Kraków, Poland \\ •Corresponding author: rzadamcz@cyfronet.pl
}

\begin{abstract}
The effect of crossbreeding Holstein-Friesian cows with other breeds is usually improved genetic potential of crossbreds in terms of longevity. However, culling decisions, which in practice determine the longevity in dairy cows, are contingent on many environmental and economic factors. Therefore, the aim of this study was to evaluate longevity in relation to culling reasons in HolsteinFriesian cows of the Black-and-White strain (HO) and crossbreds, taking genotype, age at first calving, herd size, culling season, culling reason and milking temperament into consideration. The data analysed concerned 154,256 dairy cows culled in Poland in 2015. It was found that all studied factors significantly affected cow lifetime performance. The mean age at culling in dairy cows of HO strain exceeded 6 years, with mean lifetime energy-corrected milk (LECM) yield of 28,933 kg and mean lifetime energy-corrected milk yield per milking day (DECM) of $20.2 \mathrm{~kg}$. Crossbreds, on the other hand, tended to have shorter lifespans, with mean LECM yield amounting to less than $25,000 \mathrm{~kg}$. Mean LECM yield of cows surviving for the longest period (9.2 years), amounted to $47,771 \mathrm{~kg}$, and reproduction problems were unquestionably the most common $(40 \%)$ reason for cows' culling. A suggestion was made to take milking temperament into account in breeding practice, as this trait proves to be closely related to the longevity characteristics of dairy cows. It was also proposed that the culling reasons be subjected to a more comprehensive analysis, considering the "life history" of cows as well as the interactions between different reasons for their removal from the herd.
\end{abstract}

Key words: cattle breeding, animal welfare, farm management

Among all dairy cattle in the world, the Holstein-Friesian breed (HF) has the highest genetic potential in terms of milk yield. The outstanding productivity of HF

*Work financed from the funds for statutory activity, by the Ministry of Science and Higher Education in Poland. 
cows is best achieved in conditions of their intensive use (Knaus, 2009). Unfortunately, simultaneously, the length of productive life of HF cows very often does not exceed 3 lactations, and the direct reasons for culling are usually unintended by breeders (Adamczyk et al., 2017). This is despite the fact that the practice of Holstein-Friesian cattle breeding in the world has a long-held trend towards increasing the importance of functional traits at the expense of productive traits (Egger-Danner et al., 2015). For example, functional traits in the Polish selection index have been taken into account since 2007 and their weight currently amounts to 60\% (NRIAP, 2016). Functional traits such as longevity are, however, lowly heritable, and this significantly impedes the achievement of satisfactory genetic improvement for them. In such cases, increasingly widespread genomic selection can prove helpful, which, due to a significant reduction of the generation interval, produces the possibility of substantially accelerating genetic progress (Boichard and Brochard, 2012; Pritchard et al., 2013).

The alternative solution for very intensive use of HF cows is obtaining milk from HF crossbreds (Yarbrough and Washburn, 2014). Counteracting excessive inbreeding of cows at the herd level, improving health of crossbreds and improving milk quality are usually pointed out as obvious advantages of this solution, which in turn contribute to the extension of the animals' productive life. Although keeping cows in the herd for longer periods of time does not guarantee their high lifetime performance, the total economic efficiency of using crossbreds can be high (Buckley et al., 2014; De Jong, 2014). No wonder that many milk producers keep crossbreds of HF with other breeds. For example in Poland, in 2006, these animals accounted for $0.7 \%$ of total numbers of cows covered by milk recording, while in 2015 it was already 7.1\% (PFCB, 2007; PFCB, 2016).

The decision regarding the choice of the scale (including herd size) and system of milk production is made by the farmers/breeders, based on knowledge, experience and intuition in terms of predicting future operating conditions, including local and global economic trends regarding, for example, farm-gate milk prices. Exactly how voluntary this choice is can be limited by the climate and soil conditions, the availability of production resources (fields, feedstuffs, capital) and current as well as expected economic situation (Yan et al., 2011; Martin-Collado et al., 2015). Decisions on culling, especially in the intensive systems of milk production, are most often only partly intended by the breeder. Usually, they are a forced reaction of breeders to circumstances within a herd (De Vries, 2013).

Systematic analysis of the traits related to cows' longevity helps in assessing their welfare. It can be also very helpful in considering the real underlying cause of culling decisions made by dairy farmers (FAWC, 2009; Rushen and de Passillé, 2013). The complexity of factors that ought to be considered in the decision-making process on culling makes it a difficult task and it is often hard to identify unequivocally why the farmers decide to remove the animal from the herd, to what extent this decision is voluntary, and to what extent unintended (Fetrow et al., 2006). Additionally, studies indicate that one of the important factors affecting the lifespan of dairy cows may also be the age of the first calving (Nilforooshan and Edriss, 2004; Curran et al., 2013) and even the season, among others, due to heat stress, exerting a nega- 
tive impact on animal milk performance and fertility (Walsh et al., 2011; Das et al., 2016). On the other hand, there are relatively few current works on the motivation of breeders to cull cows due to their bad temperament. It is puzzling because, although temperament is not a trait usually included in selection indexes, it is however regularly evaluated by the associations of cattle breeders around the world (Adamczyk et al., 2013; Haskell et al., 2014; Sawa et al., 2017).

Therefore, the aim of this study was the evaluation of the longevity and causes of culling in Holstein-Friesian cows of the Black-and-White strain (HO) and crossbreds of this strain in 2015 in Poland, with regard to genotype, age of first calving, herd size, season and reason for culling, and animals' milking temperament.

\section{Material and methods}

\section{Animals}

The data set comprised the records of 154,256 Holstein-Friesian cows of the Black-and-White strain (HO) and crossbreds of this strain culled in Poland in 2015 (Table 1). Cows were under milk production control within the SYMLEK system in accordance to the ICAR (2012) principles.

\section{Data editing and determination of the experimental classes}

Dependent variables in the analyses were: age at culling, mean lifetime energycorrected milk yield per milking day (DECM), lifetime energy-corrected milk yield (LECM), and mean calving interval per cow.

LECM and DECM values were calculated according to the formula of Sjaunja et al. (1990) and its modified version:

$$
L E C M=M \times(383 \times M F+242 \times M P+783.2) / 3140
$$

where:

LECM - lifetime energy-corrected milk yield $(\mathrm{kg})$,

$M$ - lifetime milk yield $(\mathrm{kg})$,

$M F$ - mean lifetime milk fat content (\%),

$M P$ - mean lifetime milk protein content (\%).

$$
D E C M=(M / M D) \times(383 \times M F+242 \times M P+783.2) / 3140
$$

where:

$D E C M$ - mean lifetime energy-corrected milk yield per milking day (kg),

$M$ - lifetime milk yield $(\mathrm{kg})$,

$M D$ - number of milking days,

$M F$ - mean lifetime milk fat content ( $\%)$,

$M P$ - mean lifetime milk protein content (\%). 


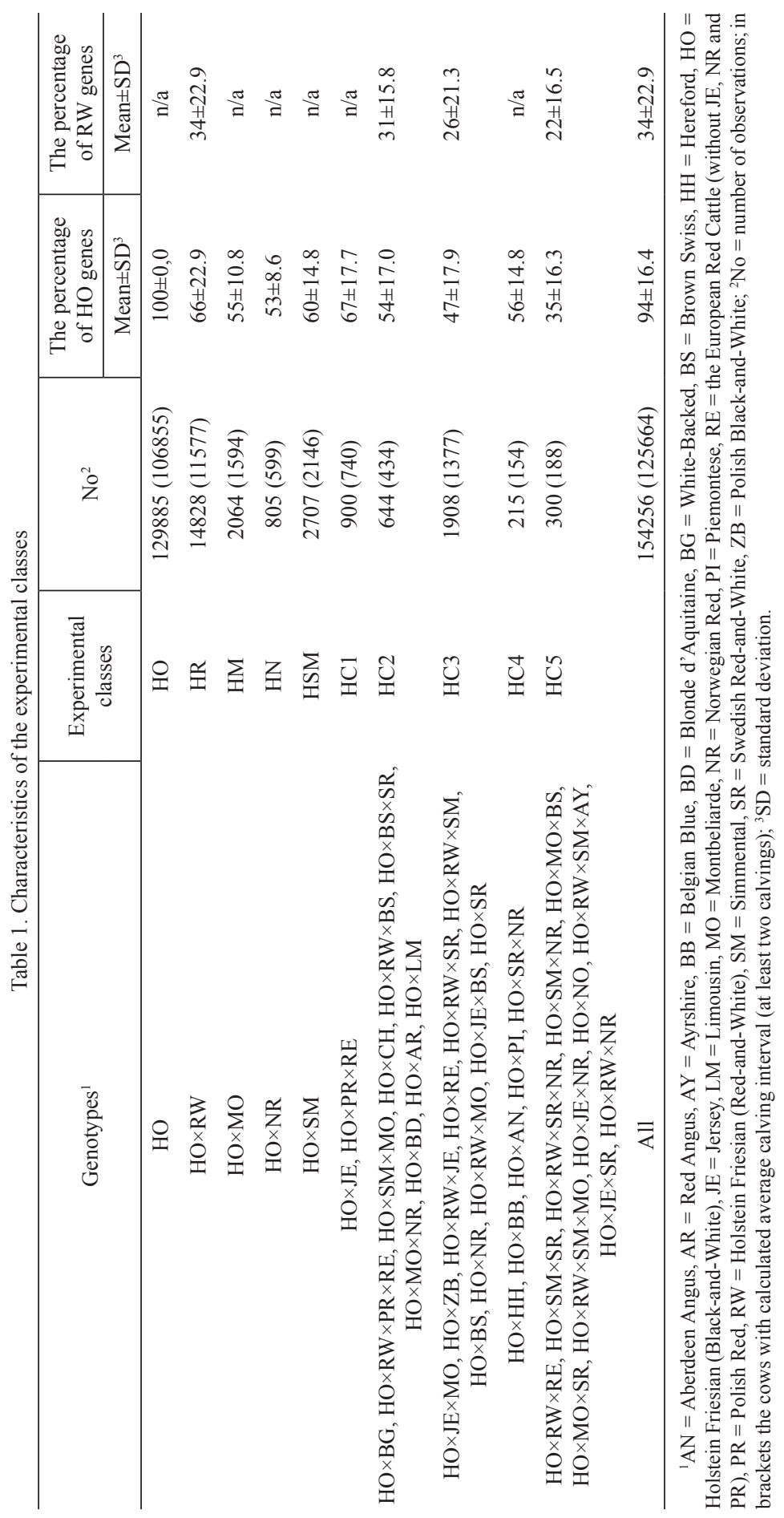


The most numerous genetic groups of over 500 cows ( $\mathrm{HO}$ and its crossbreds with HF Red-and-White strain, Montbeliarde, Norwegian Red, Simmental) were automatically classified as experimental classes (Table 1). The remaining pool consisted of many less numerous groups - crossbreds of HF and other breeds (5-500 cows within the group). Therefore, the selection of experimental classes in this case was made using Ward's cluster analysis, while simultaneously taking into account all dependent variables. The number and the composition of experimental classes were determined by the cubic clustering criterion (CCC), pseudo F (PSF) and $\mathrm{t}^{2}$ (PST2) statistics calculated for each level of the classification tree (SAS Institute Inc., 1999). The experimental classes $\mathrm{HC} 1, \mathrm{HC} 2, \mathrm{HC} 3, \mathrm{HC} 4, \mathrm{HC} 5$ were therefore determined.

\section{Statistical analysis}

Data were analysed by means of the SAS GLM procedure (SAS Institute Inc., 2008). The significance of the main effects was validated by F-test, and then differences between the means were verified using the Scheffe's test. The following linear model was applied:

$$
Y_{i j k l m n o}=\mu+G_{i}+H_{j}+A_{k}+S_{l}+C_{m}+T_{n}+C_{i j k l m n o}
$$

where:

$Y_{i j k m n o}$ - observation (for primiparous cows: age at culling or LECM or DECM, for multiparous cows: age at culling or LECM or DECM or mean calving interval),

$\mu$ - overall mean,

$G_{i}$ - effect of $\mathrm{i}^{\text {th }}$ genotype's group (HO, HR, HM, HN, HSM, HC1, HC2, HC3, $\mathrm{HC} 4)$,

$H_{j}$ - effect of $\mathrm{j}^{\text {th }}$ herd size ( $<50$ cows; $50-100$ cows; $>100$ cows),

$A_{k}$ - effect of $\mathrm{k}^{\text {th }}$ age at first calving (<23 mo.; 23-31 mo.; >31 mo.),

$S_{l}$ - effect of $1^{\text {th }}$ culling season (January to March, April to June, July to September, October to December),

$C_{m}$ - effect of $\mathrm{m}^{\text {th }}$ culling reason (old age, low milk yield, infertility and reproduction problems, udder diseases, leg diseases, nutritional and metabolic diseases, respiratory system diseases, infectious diseases, accidents, other),

$T_{n}$ - effect of $\mathrm{n}^{\text {th }}$ milking temperament of cows (very slow, adequate, excitable),

$\epsilon_{i j k l m n o}$ - random error.

Herd size classes were determined based on the herd size distribution in Poland in 2015 and related conditions of milk production both in purebred HO cows and their crossbreds (PFCB, 2016). Classes of age at first calving were distinguished based on the mean and the standard deviation (SD). Cows whose calving age was lower than the mean-SD were assigned to the first class, cows calving at the age of the mean $\pm \mathrm{SD}$ to the second, and cows calving later than the mean $+\mathrm{SD}$ to the third. Both culling reasons and milking temperament were defined according to the terminology used in the cow performance recording system by the Polish Federation of Cattle Breeders and Dairy Farmers. Milking temperament (MT) was described and understood as the cow's behaviour during milking. The MT score of the cow was 
subjective and was assessed by the farmer during the cow's first lactation, compared to the behaviour of other cows in the herd.

Additionally, the percentage share of culling reasons within each analysed experimental class was calculated (Table 4).

\section{Results}

Cows from the classes classified using cluster analysis turned out to be highly genetically diverse (Figure 1). The most homogeneous class in this case was definitely the $\mathrm{HC} 1$ class, consisting of crossbreds of $\mathrm{HO}$ with red breeds (JE, PR and RE cows). These animals, when compared to the other crossbreds, were characterized by the most similar longevity characteristics to HO cows (Table 2). Also, the HC4 class was rather genetically homogeneous, mainly (95\%) consisting of 2-breed $\mathrm{HO}$ crossbreds with beef cow genes $(\mathrm{HH}, \mathrm{BB}, \mathrm{AN}, \mathrm{PI})$. Among all experimental classes this class of cows was least intensively used (DECM $=16.4 \mathrm{~kg}$ ), with lifetime productivity amounting to only $18,396 \mathrm{~kg}$ of energy-corrected milk (ECM) (Tables 1 and 2).

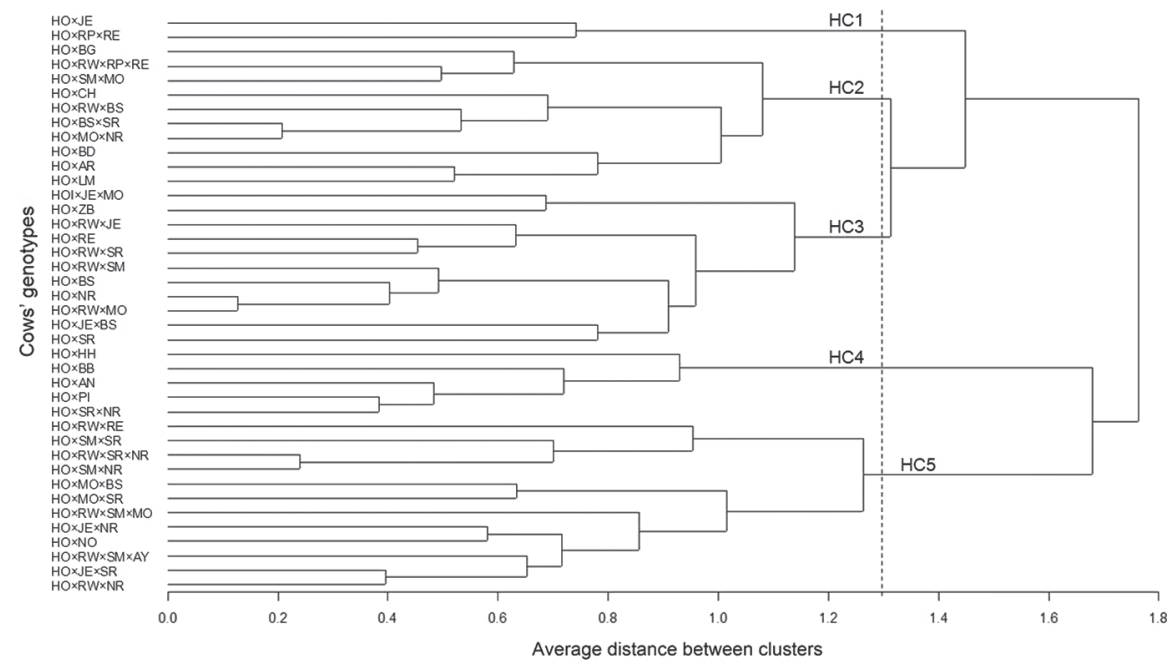

Figure 1. Tree diagram of the cows' genotypes clusters determined by the Ward method. The dotted line marks cut-off line. The names of the classified groups (HC1, HC2, HC3, HC4, HC5) were placed directly above the adequate branch

In most cases, $\mathrm{HO}$ cows excelled at longevity in comparison to other animals (Table 2). Their culling age was 6.3 years and their lifetime productivity was 28,933 $\mathrm{kg}$ ECM. Moreover, the $\mathrm{HO}$ cows achieved this result despite being among the most intensively used $(\mathrm{DECM}=20.2 \mathrm{~kg})$. On the other hand, cows from class HC5 had the shortest lifespans (4.9 years), with lifetime productivity of less than $18,000 \mathrm{~kg}$ of ECM. 


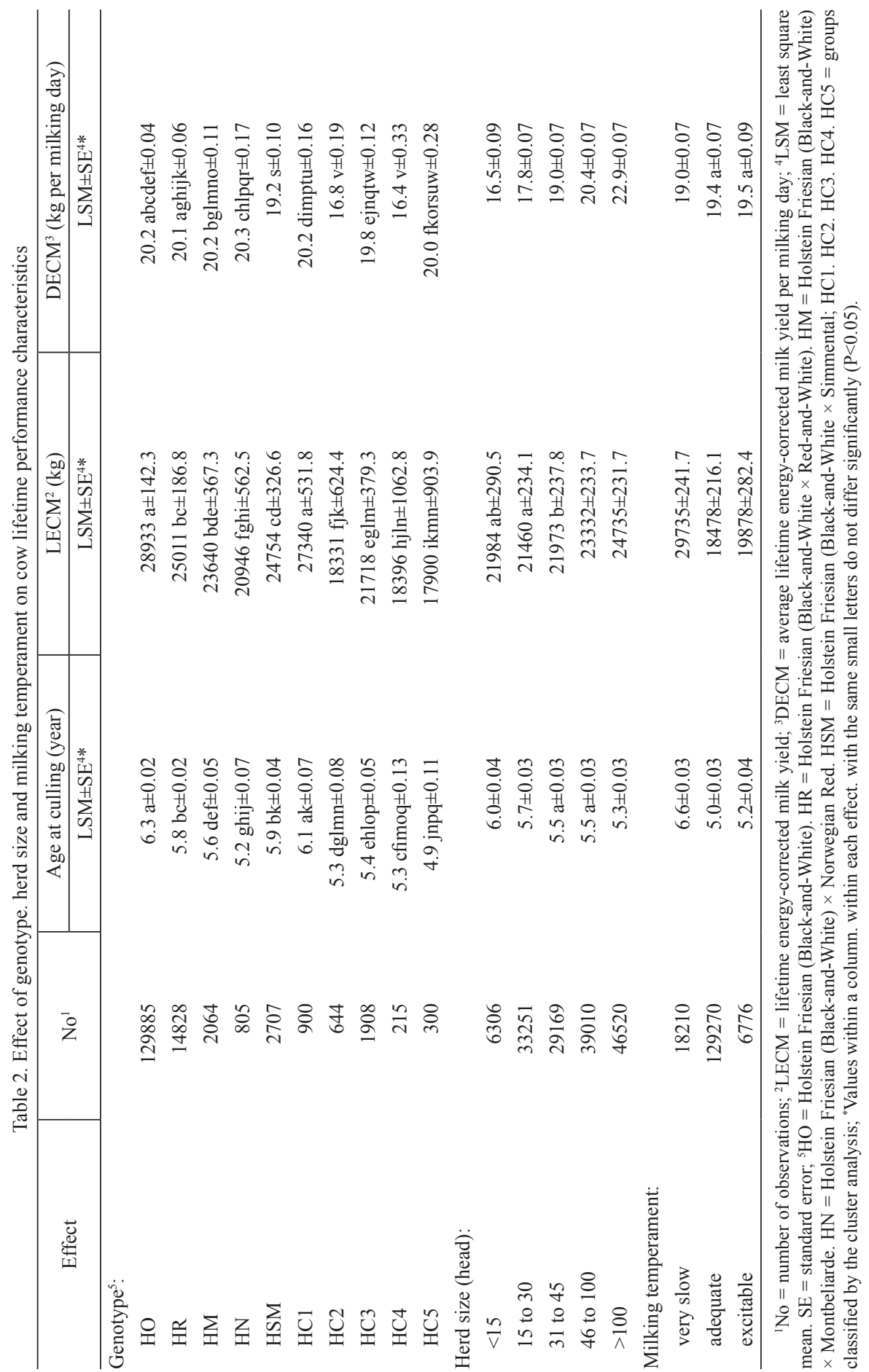




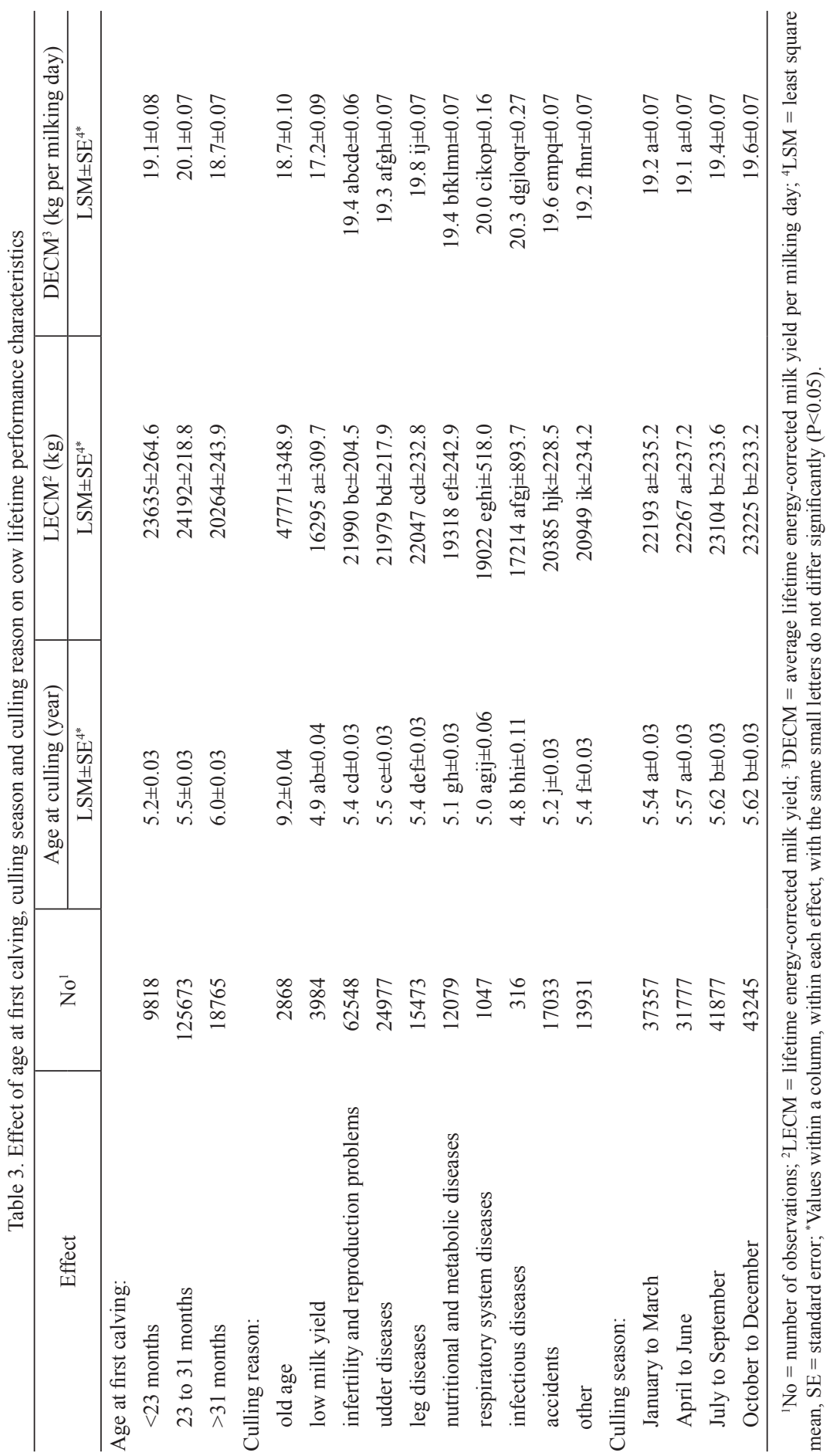




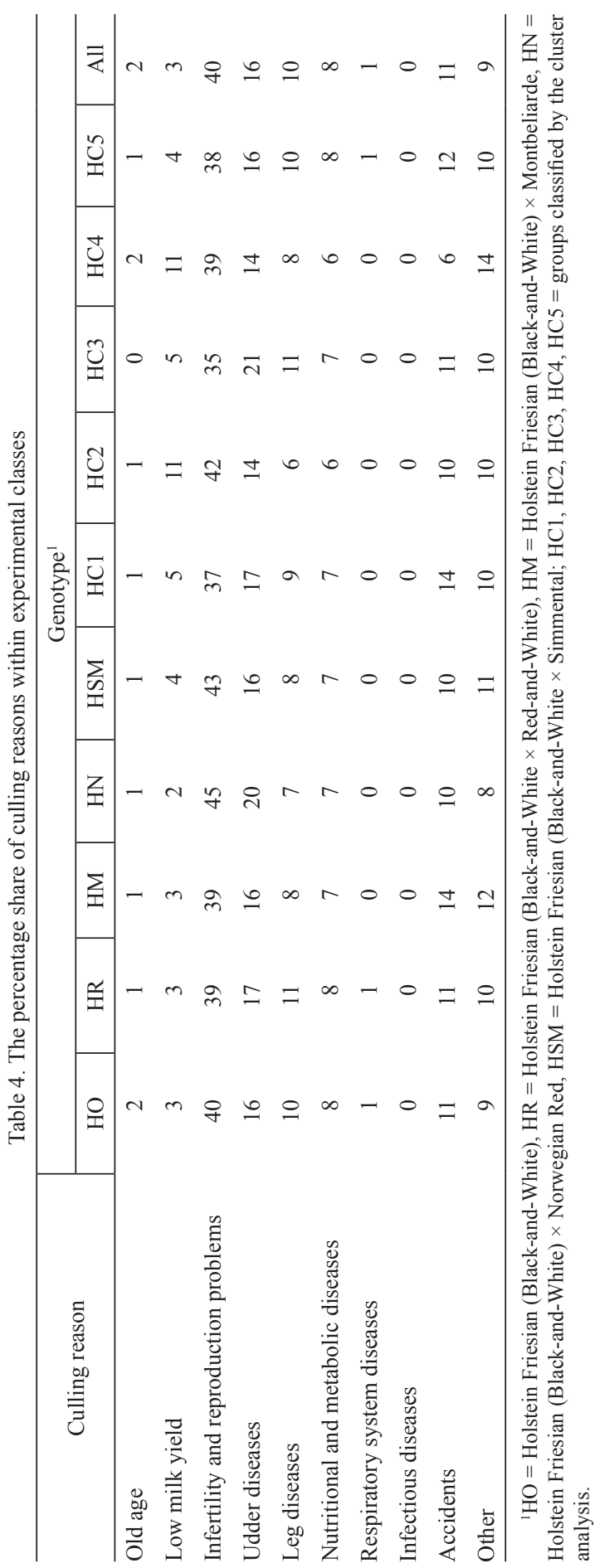


It was also found that the DECM, reflecting the level of using intensity of cows, systematically increased along with the herd size from $16.5 \mathrm{~kg}$ to $22.9 \mathrm{~kg}$ (Table 2) all differences between means were statistically significant at $\mathrm{P}<0.0001$. Such a trend has not been observed with regard to LECM, which was probably also significantly affected by the cows' lifespan. Lifetime productivity of cows in the smallest herds (less than 46 cows) amounted to approximately 21,500 to 22,000 kg ECM, whereas cows in herds of 46 to 100 and over 100 individuals had significantly higher LECM $(23,332$ and $24,735 \mathrm{~kg}$, respectively). The reverse trend was observed in the case of culling age: cows from the smallest herds had the longest lifespans (6.0 years), while cows from herds of more than 100 animals $(\mathrm{P}<0.0001)$ were characterized by the shortest lifespans (5.3 years).

Comparison of cows based on their MT showed that the calmest animals had the longest lifespans (6.6 years) (Table 2 ) while also having the highest lifetime productivity $(29,735 \mathrm{~kg}$ ECM). Whereas, somewhat contrary to expectations, cows with an average MT had the shortest lifespans, and despite the same intensity of using (19.4 to $19.5 \mathrm{~kg}$ DECM), turned out to be statistically significantly $(\mathrm{P}<0.0001)$ worse in terms of lifetime productivity than the excitable cows (18,478 and 19,878 $\mathrm{kg}$ ECM, respectively).

Characteristics of longevity in cows were significantly $(\mathrm{P}<0.0001 ; \mathrm{P}=0.0028)$ influenced by the age of their first calving (Table 3). Generally, the older the age of first calving, the longer lifespan they had and the difference between the average lifespan in the extreme classes was 0.8 years. Such a tendency was not affirmed in the case of LECM, as the highest lifetime productivity $(24,192 \mathrm{~kg} \mathrm{ECM})$ was found in cows that were first calved at the age of 23 to 31 months. These animals also proved to be the most intensively used (20.1 kg DECM).

Only approximately $2 \%$ of cows were culled due to old age: they lived on average 9.2 years and produced 47,771 kg of ECM. They were among the least intensively used animals (18.7 kg DECM). By far the most cows were culled due to reproductive problems (41\%) and thereafter due to udder diseases (16\%), accidents (11\%) and leg diseases $(10 \%)$. Cows culled for reasons other than old age lived on average 5.5 years maximum, producing no more than 22,047 $\mathrm{kg}$ ECM, with a daily yield of 17.2 to $20.3 \mathrm{~kg}$ ECM (Table 3). At this point, it is worth to refer to the results concerning the characterization of the reasons for culling within particular genotypes (Table 4), because these results correspond to those in Tables 2 and 3. It is especially interesting that the frequency of culling reasons proved to be very similar for all genetic groups. $\mathrm{HO}$ cows were not only not the worst in this respect, but in some cases (e.g. old age) they turned out to be better than most cows from other groups.

Analysing the results of the relation between cow culling season in 2015 and the longevity traits, we can observe differences between the first and the second half of the year (Table 3). During the first two quarters of the year, slightly younger individuals (5.54 and 5.57 years, respectively), characterized by lower lifetime productivity $(22,193$ and $22,267 \mathrm{~kg}$ ECM, respectively) were culled than in the following months. Animals that were culled in the first half of the year were slightly less intensively used (approx. 19.2 kg DECM). In addition, it can be observed that in the period of January-June, 10\% fewer cows were culled than in the period of July-December and both $\mathrm{HO}$ and crossbreds showed the same culling pattern (see Table 3). 
Table 5. Effect of genotype, herd size and milking temperament of cow on its average calving interval

\begin{tabular}{|c|c|c|}
\hline \multirow{2}{*}{ Effect } & \multirow{2}{*}{$\mathrm{No}^{1}$} & Average calving interval (days) \\
\hline & & $\mathrm{LSM} \pm \mathrm{SE}^{2 *}$ \\
\hline \multicolumn{3}{|l|}{ Genotype $^{3}$} \\
\hline $\mathrm{HO}$ & 106855 & $446 \mathrm{ABCDEFGHa} \pm 0.9$ \\
\hline HR & 11577 & 440 AIJKLNMO \pm 1.2 \\
\hline HM & 1594 & $427 \mathrm{BI} \pm 2.4$ \\
\hline $\mathrm{HN}$ & 599 & $420 \mathrm{CJ} \pm 3.8$ \\
\hline HSM & 2146 & $419 \mathrm{DK} \pm 2.1$ \\
\hline $\mathrm{HC} 1$ & 740 & $430 \mathrm{E} \pm 3.4$ \\
\hline $\mathrm{HC} 2$ & 434 & $428 \mathrm{aL} \pm 4.4$ \\
\hline $\mathrm{HC} 3$ & 1377 & $422 \mathrm{FM} \pm 2.6$ \\
\hline $\mathrm{HC} 4$ & 154 & $403 \mathrm{GN} \pm 7.2$ \\
\hline HC5 & 188 & $405 \mathrm{HO} \pm 6.6$ \\
\hline \multicolumn{3}{|l|}{ Herd size (head) } \\
\hline$<15$ & 5252 & $424 \pm 1.9 \mathrm{~A}$ \\
\hline 15 to 30 & 27088 & $426 \pm 1.6 \mathrm{~B}$ \\
\hline 31 to 45 & 23777 & $427 \pm 1.6 \mathrm{C}$ \\
\hline 46 to 100 & 31643 & $426 \pm 1.6 \mathrm{D}$ \\
\hline$>100$ & 37904 & $419 \pm 1.6 \mathrm{ABCD}$ \\
\hline \multicolumn{3}{|l|}{ Milking temperament } \\
\hline very slow & 17297 & $424 \pm 1.6$ \\
\hline adequate & 102820 & $424 \pm 1.5$ \\
\hline excitable & 5547 & $424 \pm 1.9$ \\
\hline
\end{tabular}

${ }^{1} \mathrm{No}=$ number of observations; ${ }^{2} \mathrm{LSM}=$ least square mean; $\mathrm{SE}=$ standard error; ${ }^{3} \mathrm{HO}=$ Holstein Friesian (Black-and-White), HR $=$ Holstein Friesian (Black-and-White $\times$ Red-and-White), HM $=$ Holstein Friesian (Black-and-White) $\times$ Montbeliarde, $\mathrm{HN}=$ Holstein Friesian (Black-and-White) $\times$ Norwegian Red, HSM = Holstein Friesian (Black-and-White $\times$ Simmental; HC1, HC2, HC3, HC4, HC5 = groups classified by cluster analysis; ${ }^{*}$ Values within a column, within each effect, with the same letters differ significantly at $\mathrm{P}<0.05$ (small letters) or $\mathrm{P}<0.01$ (capital letters).

The average length of calving interval of cows (CI) from individual genetic classes was generally proportional to their lifetime productivity and culling age (Table 5). Hence, $\mathrm{HF}$ cows, and followed by $\mathrm{HC1}$ cows, had by far the longest $\mathrm{CI}$, amounting to 446 days for $\mathrm{HO}, 440$ days for $\mathrm{HR}$, and 430 days for $\mathrm{HC} 1$. On the other hand, CI of the cows in HC4 and HC5 classes were the shortest (403 and 405 days, respectively). Moreover, on the whole, cows in herds of less than 100 animals were characterized by similar mean CI (424 to 427 days). In contrast, CI of cows from the largest herds were statistically significantly $(\mathrm{P}<0.0001, \mathrm{P}=0.0019)$ shorter (419 days). This may indicate that the detection of oestrus and the efficacy of insemination in large herds were better than in others.

As the data shows, the age of the first calving of cows statistically significantly $(\mathrm{P}<0.0001)$ affected their mean CI (Table 6). Generally, the later the cows were inseminated, the longer CI they had, and the maximum difference between the means in individual classes was 28 days. Analysing data on CI length, one can notice that 
the data regarding culling reasons proved to be particularly interesting. Contrary to expectations, infertility and reproduction problems, compared to most other culling reasons, were not associated with a significant increase in mean CI. CI values in cows culled due to reproductive problems were statistically significantly higher only in comparison with cows culled due to old age (416 days; $\mathrm{P}<0.0001$ ), udder diseases (420 days; $\mathrm{P}<0.0001$ ), and low milk yield (406 days; $\mathrm{P}<0.0001$ ).

It is also worth noting that neither cows' milking temperament nor culling season were statistically significantly associated with CI (Tables 5 and 6).

Table 6. Effect of age at first calving, culling season and culling reason of cow on its average calving interval

\begin{tabular}{|c|c|c|}
\hline \multirow{2}{*}{ Effect } & \multirow{2}{*}{$\mathrm{No}^{1}$} & Average calving interval (days) \\
\hline & & $\mathrm{LSM} \pm \mathrm{SE} 2 *$ \\
\hline \multicolumn{3}{|l|}{ Age at first calving } \\
\hline$<23$ months & 8148 & $411 \mathrm{AB} \pm 1.8$ \\
\hline 23 to 31 months & 103153 & $422 \mathrm{AC} \pm 1.5$ \\
\hline$>31$ months & 14363 & $439 \mathrm{BC} \pm 1.6$ \\
\hline \multicolumn{3}{|l|}{ Culling reason } \\
\hline old age & 2858 & $416 \mathrm{ABCDEF} \pm 2.1$ \\
\hline low milk yield & 3024 & 406 AGHIJKLM \pm 2.1 \\
\hline infertility and reproduction problems & 48191 & $429 \mathrm{BGN} \pm 1.4$ \\
\hline udder diseases & 21481 & $420 \mathrm{HNOPQR} \pm 1.5$ \\
\hline leg diseases & 13148 & $431 \mathrm{CIOS} \pm 1.5$ \\
\hline nutritional and metabolic diseases & 10454 & $430 \mathrm{DJP} \pm 1.6$ \\
\hline respiratory system diseases & 844 & $430 \mathrm{~K} \pm 3.4$ \\
\hline infectious diseases & 220 & $424 \pm 6.2$ \\
\hline accidents & 13994 & $430 \mathrm{ELQ} \pm 1.5$ \\
\hline other & 11450 & $426 \mathrm{FMRS} \pm 1.6$ \\
\hline \multicolumn{3}{|l|}{ Culling season } \\
\hline January to March & 30234 & $423 \pm 1.6$ \\
\hline April to June & 25749 & $425 \pm 1.6$ \\
\hline July to September & 34438 & $425 \pm 1.6$ \\
\hline October to December & 35243 & $423 \pm 1.6$ \\
\hline
\end{tabular}

${ }^{1} \mathrm{No}=$ number of observations; ${ }^{2} \mathrm{LSM}=$ least square mean; SE = standard error; ${ }^{*}$ Values within a column, within each effect, with the same capital letters differ significantly at $\mathrm{P}<0.01$.

\section{Discussion}

Breeding practice on $\mathrm{HO}$ cattle undertaken 10 years ago in Poland, taking into consideration functional traits in the selection index, produces measurable effects. In 2015, cows of the HO strain were culled 6 months later, having produced approx. $3600 \mathrm{~kg}$ ECM more in their productive lifetime at a similar using intensity level (20.2 to $20.8 \mathrm{~kg}$ DECM) than HO cows culled in Poland three years earlier (Adam- 
czyk et al., 2017). This study shows that, in terms of the above-mentioned criteria, HO cows culled in 2015 achieved also better results than crossbreds. According to PFCB data $(2013,2014,2017)$ in Poland, in the period from 2012 to 2016, a relatively stable length of production life of $\mathrm{HO}$ cows was recorded (3.1-3.2 years). Simultaneously, a small increase in lifetime milk productivity (from 23102 to $23699 \mathrm{~kg}$ ) was observed. In case of crossbreds, the increase in lifetime milk production (from 13018 to $17730 \mathrm{~kg}$ ) was accompanied by a gradual extension of the production lifespan of animals (from 2.1 to 2.6 years).

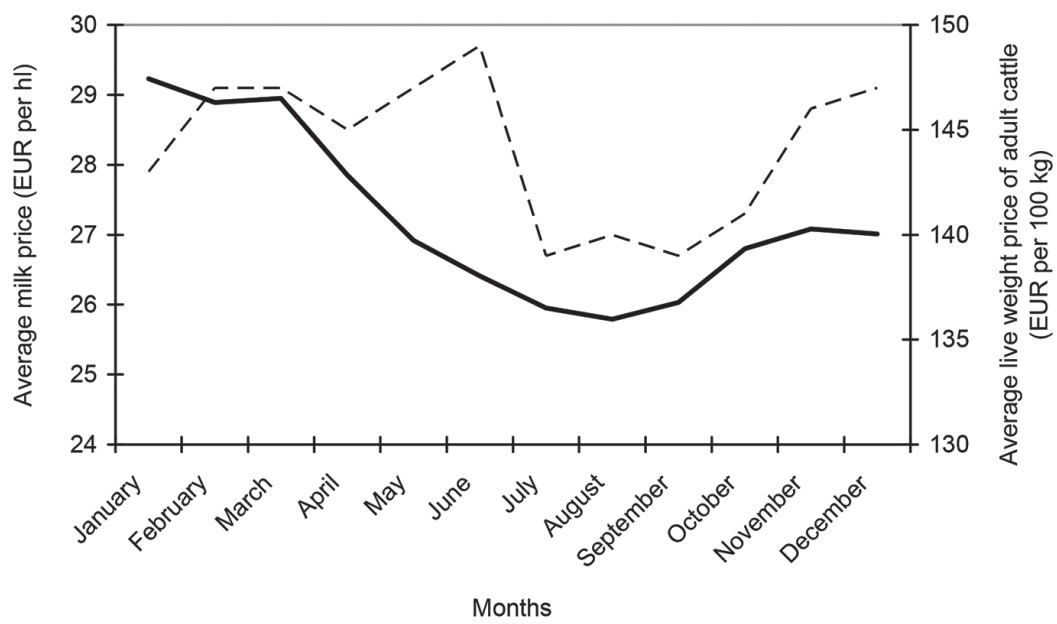

Figure 2. The average prices of milk (solid line) and live weight of slaughter adult cattle (dotted line) in Poland in 2015 (based on CSO, 2016). EUR $1=$ PLN 4.18, according to the average annual exchange rate published by the National Bank of Poland

It is commonly believed that, as a result of crossbreeding HF cows with other dairy and dual purpose breeds (and those crossbreds were prevailing in this research), an animal's longevity is generally improved - particularly in the $\mathrm{F}_{1}$ generation due to the heterosis phenomenon (McAllister, 2002; Freyer et al., 2008; Buckley et al., 2014). However, in practice, the expression of genetic potential for longevity may be limited by environmental conditions, including extrinsic economic factors. All the more so, since milk producers make decisions with regard to cow culling, putting a strong emphasis on herd profitability, which is not always conducive to longevity (De Vries, 2013). This was unequivocally confirmed by own research, in which it was found that compared to crossbreds, HO cows showed better longevity characteristics and they were not worse than crossbreds in terms of the frequency of particular culling reasons. It should be also emphasized that in 2015 the percentage of $\mathrm{HO}$ and crossbreds cows disposed from the herds was very similar and amounted to approximately $30 \%$ and $28 \%$, respectively (PFCB, 2016).

According to Kargo et al. (2012) it is a myth that the heterosis phenomenon for dairy performance traits decreases with the increase of herd management level, and the benefits of such a situation decrease with increasing milk production on a farm. 
According to these authors, any milk producer, regardless of the scale of production, ought to consider the economic benefits arising from crossbreeding cows of dairy and dual purpose breeds. It would seem that also Polish breeders, like their counterparts elsewhere, do not give up on crossbreeding, provided they consider it profitable. The results presented here regarding age at culling and LECM (Table 2) indicate that, regardless of the herd size and the production intensity, very often they keep both purebred dairy cattle and crossbreds. This is proved by the values of age at culling and LECM, which in all studied herd size classes were lower than those observed for purebred HF (HO and HR genotypes). Thus, it is most likely that a considerable number of crossbreds, generally characterized by lower age at culling and LECM, were found in all herd size classes.

When analysing the longevity traits in dairy cows culled in Poland in 2015, it is beneficial to show the economic background that might have influenced breeders' decisions. Of the prevailing economic conditions, milk producers were particularly concerned about the protracted decisions regarding the abolition of milk quotas. It was particularly important, because in 2014/2015 systematically increasing milk production in Poland exceeded national quota by approximately 6\% (580.3 million $\mathrm{kg}$ of milk). The effects of the embargo introduced by Russia on dairy products originating from the European Union countries (Kraatz, 2014) also had a substantial impact on the production decisions of the breeders. Additionally, in recent years there has been a great instability in milk prices on the world markets, which of course negatively affected the prices of milk at the country level. According to the GDT (2016), while in 2013 whole milk powder weighted average prices were at the level of \$4.6-5.2, they went down to \$2.2 in 2014 and remained at this level throughout 2015. As the farm-gate milk price was closely linked to the demand and prices of HO pregnant heifers, in this situation a faster replacement of the herd was more profitable (Krpálková et al., 2014).

In 2015 in Poland, the difference between the minimum (€26 per hl) and the maximum ( $€ 29$ per hl) farm-gate milk price was about $12 \%$, while the live weight price of adult cattle fluctuated during this time at a fairly constant level between $€ 139$ per $100 \mathrm{~kg}$ and $€ 148$ per $100 \mathrm{~kg}$ (difference of 6\%) (Figure 2). This could have prompted milk producers to accelerate their rate of cow culling - especially the owners of $\mathrm{HO} \times \mathrm{SM}$ or $\mathrm{HO} \times$ beef cattle crossbreds. In the first half of the year, the price of milk was notably going down and then began to rise slightly. This increase, however, was progressing at a lower speed than the increase of live cattle price, which was probably the reason for increased cow culling in that period (Table 3). Nonetheless, it seems that without individual, detailed economic analysis, it is difficult unambiguously to assess the financial impact of culling decisions taken at different times of the year.

Regardless of the above mentioned conditions, it is claimed that the necessity of a currently high level of specialization in dairy cow breeding under uncertain economic conditions is generally favourable to the resignation of many owners, especially of small herds, from conducting their current activity (Skarżyńska, 2013). In addition, this discontinuation is associated with the increasingly limited land resources allocated to the production of fodder crops for dairy cattle and continuously 
rising labour costs (Parzonko, 2014). Perhaps the described trend will be much more visible among Polish dairy producers in the future. So far, this research shows that cows in the smallest herds (less than 31 cows) were culled the latest of all the herds.

Due to the high instability of the profitability of HF-cow-based dairy herds in the period prior to the abolition of milk quotas, many milk producers sought alternatives, including crossbreeding less efficient HF cows with other dairy and dual purpose cow breeds. The large share of animals in dual purpose type and beef breeds used as crossbreeding components for HF cows (e.g. HSM, HC2, HC4 classes) in this research indicates that, by doing this kind of crossbreeding, many milk producers were likely to count on an additional source of income, namely the sale of live cattle, in order at least to wait out the unfavourable economic situation regarding milk production.

Delays in culling purebred Holstein-Friesian cows and the improvement in their lifetime performance in the years 2012-2015 indicate that their owners basically reacted reasonably to relatively unfavourable economic conditions, deciding to take advantage of the growing genetic potential of these animals in terms of longevity, while hoping for better economic conditions and greater profitability in the future. Crossbreeding was conducted on a rather limited scale at that time. Crossbreeding with other dairy breeds, however, made it possible to improve the quality of milk (protein and fat content) and, when crossing with bulls of beef breeds, to obtain alternative income from the sale of live cattle.

An increase in dairy cow longevity and lifetime performance can be achieved by improving the characteristics associated with them directly or indirectly. Current monitoring possibilities provide a lot of valuable information in regard to each animal within the herd. Wide availability of routine herd data allows not only ongoing decisions regarding the herd, but also the incorporation of important new traits into the genetic improvement programmes. One such trait is milking temperament, which, as was proved in the present study, is closely related to the longevity of cows and their lifetime performance. It was unequivocally confirmed that selection should favour the calmest cows and eliminate the ones of average and excitable temperament from the herd. The study of Schaeffer et al. (2011) performed on the Canadian dairy cattle population shows that MT of $\mathrm{HF} \times$ Brown Swiss, $\mathrm{HF} \times$ Jersey, $\mathrm{HF} \times$ Norwegian Red and $\mathrm{HF} \times$ Swedish Red crossbreds were relatively similar to purebred HolsteinFriesian cows. This suggests that the aforementioned selection criterion could be used both in HF herds and its crossbreds with other dairy breeds. Meanwhile, MT is most often not included in the breeding programmes for dairy cattle worldwide. Only in some countries, mainly Scandinavian, has this task been undertaken (Adamczyk et al., 2013).

Another interesting issue, in our opinion, is the relationship between the longevity traits in cows and culling reasons. Both scientific research and breeding practice usually analyse only the direct reason for cow culling (ICAR, 2012; Compton et al., 2017). This, however, seems not to be sufficient, as this approach assumes lack of other important factors directly affecting the longevity of cows during their lifetime (i.e. the effects of past diseases) and, in addition, it does not take into account the interactions between different culling reasons (e.g. the relationship between lame- 
ness and reproductive problems). It seems that a more comprehensive approach to this issue could provide more definite answers to some questions. For example, this study found that the mean CI of cows culled due to reproductive problems (429 days) was similar to the one of animals removed from the herd for most other causes. It is difficult, however, to interpret these results unambiguously, as it was rather expected that reproductive problems would cause the pronounced elongation in CI. Probably the analysis of the "life history" of each individual and the interrelationships between indirect and direct culling reasons would shed more light on this problem. In addition, this study found a large share (20\% in total) of cows culled due to accidents and "other causes" - a somewhat ambiguous explanation for culling from the herd. The problems indicated in this paragraph in practice depend to a large extent on the cooperation between milk farmers/producers and veterinarians. According to Ventura et al. (2016), "occasional" communication between them, limited mainly to the situations related to the treatment of animals, is definitely not enough. A systematic, daily control aimed at providing animals with optimal welfare should cover all dairy cattle herd and not only individuals currently requiring veterinary intervention. What is more, taking into account a continuous increase in knowledge on the principles of animal welfare improvement, each person having a direct contact with animals should be motivated to systematically update his competences in this area (Gibson, 2011).

\section{Conclusions}

Both genotype and other experimental factors significantly influenced cow lifetime performance. In practice, purebred Holstein-Friesian cows of Black-and-White strain turned out not only worse than crossbreds, but in the case of two studied traits (age at culling and lifetime energy-corrected milk yield) were characterized by even more favourable values. Although the cows in the smallest herds were culled at the latest, their lifetime energy-corrected milk did not exceed 22,000 kg. Cows of adequate and excitable temperament had poorer values of longevity indicators than the calmest animals. It was also shown that the later was the age of the first calving of cows, the longer they lived, but their lifetime productivity was lower. Regardless of genotype, the majority of cows were culled due to infertility and reproduction problems. The demonstrated significant effect of culling season could be associated with fluctuations in the prices of milk and beef.

It must be stated that making use of genetic potential in terms of longevity traits depends to a large extent on numerous and complex economic and environmental factors. Decisions made by farmers with regard to the choice of genotypes, animal production system, nutrition, etc as early as the start-up stage of the dairy farm are vital for the future lifetime performance of cows. During the operation of the farm, the verification and assessment of the adopted breeding and production processes is performed, which is often associated with the necessity of taking decisions on culling some animals. In a properly planned farm operation, culling decisions, in addition to random health events in the herd, are a result of the adopted breeding strategy, being subject to modification due to changing external production and economic conditions. Because of the complexity of the causes and consequences of culling, 
taking an economically optimal decision in regard to removing an animal from the herd is not an easy task. It is suggested that such decisions be efficiently supported by specially designed analytical and simulation models. These methods might also prove useful at the stage of planning the activity of a dairy farm, since it seems that paying more attention to the planning stage of this activity can contribute to a lower amount of involuntary culling cases in future.

The complexity of the problem of longevity means that the analysis of the causes of culling ought to take into account the entire "history" of the use of the cow, and not just the reported, direct cause for its removal from the herd. This would not only clarify the factors that could have led to a situation prompting the breeder to make a decision on culling, but also provide information on possible significant problems in the herd. Also, it would be very interesting to gain knowledge about the specific socio-psychological reasons considered by the farmers while taking decisions on the culling of dairy cows.

\section{Conflict of interest statement}

The authors declare no conflicts of interest.

\section{Acknowledgements}

This study was carried out using data provided by the Polish Federation of Cattle Breeders and Dairy Farmers in Warsaw (PFCB); contract No. 36/2016 between PFCB and the University of Agriculture in Krakow; the purchase of the data was financed from the funds for statutory activity, by the Ministry of Science and Higher Education in Poland.

\section{References}

A d a m c z y k K., Pokorska J., Makulska J., Earley B., Mazurek M. (2013). Genetic analysis and evaluation of behavioural traits in cattle. Livest. Sci., 154: 1-12.

A da mczyk K., Makulska J., Jagusiak W., Węglarz A. (2017). Associations between strain, herd size, age at first calving, culling reason and lifetime performance characteristics in Holstein-Friesian cows. Animal, 11: 327-334.

B o i c hard D., B r o c hard M. (2012). New phenotypes for new breeding goals in dairy cattle. Animal, 6: 544-550.

B u ckley F., L o p e z - Vill a l o b o s N., H e in s B.J. (2014). Crossbreeding: implications for dairy cow fertility and survival. Animal, 8 (suppl. 1): 122-133.

Central Statistical Office of Poland (CSO). (2016). Procurement and prices of agricultural products in 2015 (in Polish). Available at: https://stat.gov.pl/ (verified 6 February 2017).

Compton C.W.R., Heuer C., Thom sen P.T., Carpenter T.E., Phyn C.VC., McDou g a 11 S. (2017). Invited review: a systematic literature review and meta-analysis of mortality and culling in dairy cattle. J. Dairy Sci., 100: 1-16.

Curran R.D., Weigel K.A., Hoffman P.C., Marshall J. A., Kuzdas C.K., Coblentz W.K. (2013). Relationships between age at first calving; herd management criteria; and lifetime milk, fat, and protein production in Holstein cattle. The Professional Animal Scientist, 29: $1-9$.

D a s R., S a ilo L., Verma N., Prana y B., Jny a n a shree S., Imtiwati K u mar R. (2016). Impact of heat stress on health and performance of dairy animals: A review. Vet. World, 9: 260-268. 
D e J o n g G. (2014). Lifetime production index, what cows really can produce. Interbull Bulletin, 48: $54-57$.

Demeter R.M., Kristensen A.R., Dijkstra J., Oude Lansink A.G.J.M., Meuwiss en M.P.M., van A rendonk J.A.M. (2011). A multi-level hierarchic Markov process with Bayesian updating for herd optimization and simulation in dairy cattle. J. Dairy Sci., 94: 5938-5962.

D e Vrie s A. (2013). Cow longevity economics: The cost benefit of keeping the cow in the herd. Proc. the Conference: Cow Longevity Conference, Hamra Farm/Tumba, Sweden, pp. 22-52.

Egger-Danner C., Cole J.B., Pryce J.E., Gengler N., Heringstad B., Bradley A., S tock K.F. (2015). Invited review: overview of new traits and phenotyping strategies in dairy cattle with a focus on functional traits. Animal, 9: 191-207.

Farm Animal Welfare Council (FAWC). (2009). Opinion on the welfare of the dairy cow. Available at: https://www.gov.uk/ (verified 26 January 2017).

Fetrow J., N ord l und K.V., N or m an H.D. (2006). Culling: nomenclature, definitions, and recommendations. J. Dairy Sci., 89: 1896-1905.

Freyer G., König S., F ischer B., B erg feld U., Cas sell B.G. (2008). Invited review: crossbreeding in dairy cattle from a German perspective of the past and today. J. Dairy Sci., 91: 3725-3743.

G i b s o n M. (2011). The Universal Declaration of Animal Welfare. Deakin Law Review, 16: 539-567.

Global Dairy Trade (GDT). (2016). Whole milk powder prices. Available at: https://www.globaldairytrade.info/ (verified 3 February 2017).

H a s k e 11 M.J., S i m m G., T u r n e r S.P. (2014). Genetic selection for temperament traits in dairy and beef cattle. Front Genet., 5: 368.

International Committee for Animal Recording (ICAR). (2012). International agreement of recording practices. Available at: http://www.icar.org/ (verified 5 May 2013).

K a rg o M., M a d s en P., N or b e r g E. (2012). Short communication: is crossbreeding only beneficial in herds with low management level? J. Dairy Sci., 95: 925-928.

K n a u s W. (2009). Dairy cows trapped between performance demands and adaptability. J. Sci. Food Agric., 89: 1107-1114.

K r a a $\mathrm{z}$ S. (2014). The Russian embargo: impact on the economic and employment situation in the EU. Employment and Social Affairs. Available at: http://www.europarl.europa.eu/ (verified 7 February 2017).

Krpálková L., Cabrera V.E., Kvapilík J., Burdych J., Crump P. (2014). Associations between age at first calving, rearing average daily weight gain, herd milk yield and dairy herd production, reproduction, and profitability. J. Dairy Sci., 97: 6573-6582.

Martin-Collado D., Byrne T.J., Amer P.R., Santos B.F.S., Axford M., Pryce J.E. (2015). Analyzing the heterogeneity of farmers' preferences for improvements in dairy cow traits using farmer typologies. J. Dairy Sci., 98: 4148-4161.

M c A 11 i s t e r A.J. (2002). Is crossbreeding the answer to questions of dairy breed utilization? J. Dairy Sci., 85: 2352-2357.

National Research Institute of Animal Production (NRIAP). (2016). Evaluation of breeding value of Black-and-White and Red-and-White Holstein-Friesian bulls. (In Polish). Available at: http://wycena.izoo.krakow.pl (verified 8 December 2016).

Ni e 1 s e n L.R., Jørge n s en E., K risten s en A.R., Ø st e rg a ard S. (2010). Optimal replacement policies for dairy cows based on daily yield measurements. J. Dairy Sci., 93: 75-92.

Nil for o o sh an M.A., Edris s M.A. (2004). Effect of age at first calving on some productive and longevity traits in Iranian Holsteins of the Isfahan Province. J. Dairy Sci., 78: 2130-2135.

Parzonko A. (2014). Economic and social issues related with the development of dairy farms in Poland. Proc. the Conference: Economic Science for Rural Development, Jelgava, Latvia, pp. 197-207.

Polish Federation of Cattle Breeders and Dairy Farmers in Warsaw (PFCB). (2007). The results of productive value of dairy cows recorded in Poland in 2006 (in Polish). Available at: http://www.pfhb. pl/ (verified 1 December 2016).

Polish Federation of Cattle Breeders and Dairy Farmers in Warsaw (PFCB). (2013). The results of productive value of dairy cows recorded in Poland in 2012 (in Polish). Available at: http://www.pfhb. pl/ (verified 1 December 2016). 
Polish Federation of Cattle Breeders and Dairy Farmers in Warsaw (PFCB). (2014). The results of productive value of dairy cows recorded in Poland in 2013 (in Polish). Available at: http://www.pfhb. $\mathrm{pl} /$ (verified 20 June 2014).

Polish Federation of Cattle Breeders and Dairy Farmers in Warsaw (PFCB). (2016). The results of productive value of dairy cows recorded in Poland in 2015 (in Polish). Available at: http://www.pfhb. pl/ (verified 28 November 2016).

Polish Federation of Cattle Breeders and Dairy Farmers in Warsaw (PFCB). (2017). The results of productive value of dairy cows recorded in Poland in 2016 (in Polish). Available at: http://www.pfhb. $\mathrm{pl} /$ (verified 22 January 2018).

Pritch ard T., C offe y M., Mrode R., Wall E. (2013). Understanding the genetics of survival in dairy cows. J. Dairy Sci., 96: 3296-3309.

Rushen J., de Passillé A.M. (2013). The importance of improving cow longevity. Proc. of the Cow Longevity Conference, Hamra Farm/Tumba, Sweden, pp. 3-21.

S a w a A., B o g u cki M., N ej a W., K ręż e l-Czopek S. (2017). Effect of temperament on performance of primiparous dairy cows. Ann. Anim. Sci., 17: 863-872.

$\mathrm{Sch}$ a effer L.R., B urnside E.B., G lover P., F a t e hi J. (2011). Crossbreeding results in Canadian dairy cattle for production, reproduction and conformation. Open Agric., 5: 63-72.

S j a un j a L.O., B a evre L., J unk karin en L., P e d ers en J., S e t a la J. (1990). A Nordic proposal for an energy corrected milk (ECM) formula. Proc. of the 27th Biennial Session of the International Committee for Animal Recording (ICAR), Paris, France, pp. 156-192.

S k a r ż y ń s k a A. (2013). The opportunities of generating income at the parity level by farms specializing in milk production in Poland. J. Cent. Eur. Agr. 14: 149-165.

Ventura B.A., We ary D.M., G i ov a netti A.S., von Keys er 1 ing k M.A.G. (2016). Veterinary perspectives on cattle welfare challenges and solutions. Livest. Sci., 193: 95-102.

W a $1 \mathrm{sh}$ S.W., Wi 11 i a m s E.J., E $\mathrm{v}$ a $\mathrm{n}$ s A.C.O. (2011). A review of the causes of poor fertility in high milk producing dairy cows. Anim. Reprod. Sci., 123: 127-138.

Y a n M.-J., H u m phre y s J., Hold en N.M. (2011). An evaluation of life cycle assessment of European milk production. J. Environ. Manage., 92: 372-379.

Yarbro u g h R.J., W a s h bu r n S. (2014). Crossbreeding - is it a good option? Abstract Book of Joint Annual Meeting, Kansas City, Missouri, USA, pp. 11-12.

Received: 14 V 2018

Accepted: 26 VII 2018 